\title{
Canadian Studies in Population
}

\author{
Official Journal of the \\ Canadian Population Society
}

Editor

Frank Trovato, University of Alberta

Managing Editor

Stephanie Baker, Population Research Laboratory

University of Alberta

Assistant to the Editor

Kamrul Islam

University of Alberta

Volume 36, Number 1-2, Spring/Summer, 2009 


\section{Dedication}

This edition of Canadian Studies in Population is dedicated to the memory of Professor Karol J. Krotki, a leading international demographer, who passed away on 6 July, 2007 at the age of 85. Dr. Krotki taught in the department of sociology at the University of Alberta from 1968-1991. In their In Memoriam included in this issue, Anatole Romaniuk and T.R. Balakrishnan pay tribute to this exceptional scholar, friend, and colleague.

Frank Trovato

Editor, Canadian Studies in Population 


\section{Table of Contents}

ii Dedication

Frank Trovato, Editor

$\mathrm{V}-\mathrm{X} \quad$ Professor Karol Krotki, In Memoriam (1922-2007)

Anatole Romaniuk andT.R. Balakrishnan

$\mathrm{xi}-\mathrm{xvi}$ Introduction to the Special Issue

Zheng Wu, Guest Editor

17-36 Aging and the Necessity of a Radical Reform of the Canadian Pension System

Jacques Henripin

37-62 The Conundrum of Demographic Aging and Policy Challenges: A Comparative Case Study of Canada, Japan and Korea Susan A. McDaniel, FRSC

63-86 Immigrant Language Proficiency, Earnings, and Language Policies

Monica Boyd and Xingshan Cao

87-110 Effects of Foreign Education on Immigrant Earnings

Eric Fong and Xingshan Cao

111-144 Canadian Provincial Population Growth: Fertility, Migration, and Age Structure Effects

Barry Edmonston

145-166 Family Models for Earning and Caring: Implications for Child Care and for Family Policy

Roderic Beaujot and Zenaida R. Ravanera

167-182 Book Reviews 


\section{Professor Karol Krotki, In Memoriam (1922-2007)

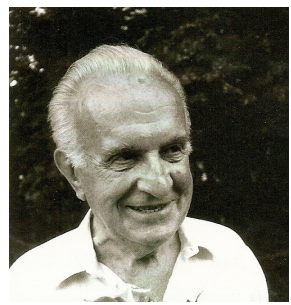

Born 15 May 1922 in Cieszyn in Poland, Karol Krotki died on 6 July 2007, at age 85, in Edmonton, his home town since 1968, when he joined the Department of Sociology at the University of Alberta. He became distinguished university professor in 1982 and retired in 1990, but continued to be professionally active till his death. The passing of Professor Krotki is a great loss to the community of demographers in Canada and beyond. A towering figure, both in the proper sense, by his imposing stature, and in the figurative, by his personality which projected warmth and wisdom. In the many roles he took on in his life - teacher, scholar, and administrator - he will be affectionately remembered.

Life was not always kind to him. As many of his generation, he was caught in the spiral of events propelled from the Second World War. His native country, Poland, vanished as a state in 1939 following invasions by Nazi Germany and Stalinist Soviet Union, and the young Karol, 17 at that time, escaped his occupied country by foot. Eventually he ended up in exile. But he did not remain inactive in the face of tragic events; he enrolled in the British Army, took part in the battles of North Africa (1941-1942), before joining the Royal Air Force in England. He earned many distinctions and decorations for his bravery in the battle field. Upon the cessation of hostilities, he decided not to return to his native Poland, fallen under the Soviet Union domination. He stayed in Great Britain to pursue his university education.

Karol earned a BA Honors (1946-1948), and an MA in Economics with statistics from Cambridge University (1952). He crowned his university education with a PhD in Economics at Princeton University (1960). His $\mathrm{PhD}$ dissertation, Estimating Vital Rates from Peculiar and Inadequate Age Distribution, using data that he collected earlier in Sudan, was completed under the supervision of Ansley Coale, the director of the Office of Population Research and the leading demographer of the second half of the 20th century. 


\section{Professional Activities in Moslem Countries}

His first professional assignment was in Sudan (1949-1958), at that time part of the British Dominion, at the Department of Statistics in Khartoum, where he eventually reached the rank of Deputy Director. His landmark achievement in Sudan was its first population census carried out between 1956-1958. His next assignment was in Pakistan. From 1960-1964, he was Research Adviser at the Institute of Economic Development in Karachi, where he was involved in teaching as well as in research in various fields of economics and demography. Later, in 1971-1972, taking advantage of a sabbatical from the University of Alberta, he went to Morocco to work in the Centre de recherches et d'études démographiques in Rabat. With these longterm missions and some short ones in various Moslem countries, Dr. Krotki deservedly earned the reputation of an expert in Moslem demography.

\section{Statistics Canada}

His long Canadian career started in 1964 with Statistics Canada, known at that time as the Dominion Bureau of Statistics. We are better documented on this phase in Dr. Krotki's career owing to Silvia Wargon's book, Demography in Canada in the Twentieth Century, and the recollections of junior colleagues of the day, M.V. George and Evelyne Lapierre-Adamcyk. As a senior demographer and bureaucrat, Dr. Krotki was in charge of managing demographic research, both substantive and methodological, population estimates and forecasting as well as the preparation towards the 1971 census, its methodology and content determination. In this capacity he brought the ground work to new heights, laid down by his two distinguished predecessors Nathan Keyfitz and Yoshiko Kasahara. He spearheaded the 1961 census monograph program, the most ambitious of its kind ever conducted by Statistics Canada. Dr. Krotki's legacy in demography in the government statistical environment is widely recognized.

\section{Professorship at the University of Alberta}

In 1968, Dr. Krotki left Statistics Canada to join the University of Alberta where he spent the rest of his life. He was instrumental in establishing a strong demography program and the Population Research Laboratory at the university. He trained many students, in class and as supervisor to their MA and $\mathrm{PhD}$ research. 
He thought them to be truly objective, unprejudiced researchers and teachers. Many have followed in his footsteps, becoming in their turn prominent teachers and researchers. He was one of those professors who continued taking interest, long after they left the university, and often inspired them in their own career paths. With typical eloquence, Susan McDaniel, who had the privilege of having Karol Krotki as a professor, speaks of how he inspired her and his students in the unprejudiced, open-minded approach to look at social problems. She writes:

Leaving our own beliefs behind trains the mind to see, to animate our sense of belonging to a bigger world, one that extends deep in history and forward into possibility. That is what Karol inspired me to try to do and be as a scholar.

Professor Krotki had his didactic methods, aptly described by another of his former students, Rod Beaujot.

For undergraduates, Dr. Krotki was an ideal professor, giving us the core and many insightful tangents, connecting us to the vast world of his professional experience. As a graduate advisor, he was exemplary in the ideas and resources he shared, his unfailing supportiveness and his strong respect for timeliness, both for his students and on his own part. For former students, Karol was forever dedicated, involved and the best of colleagues.

Karol Krotki taught a wide range of courses - population, social and economic developments, social statistics, demography of the Soviet Union and eastern Europe, ethnic and minority relations - and supervised a spectrum of MA and $\mathrm{PhD}$ students in a variety of fields of interest - reflecting his own multidisciplinary training in demography, economics, and statistics, as well his broad world-wide field experience.

In recognition of his high achievements in academia and research, in 1982, the University of Alberta awarded Dr. Krotki with the much aspired distinction of "University Professor."

\section{Publications, Scholarships}

If the dual duty of the university professor is to transmit knowledge to the next generation and contribute to its advancement, then Karol Krotki lived up to the role to the fullest. His research output is vast and lasting, and could hardly be discussed within the scope of this article. Karol authored, coauthored or edited 12 books and monographs and more than 100 scholarly articles. As highlighted by Professor Frank Trovato, his colleague: 
Karol Krotki's research interests were primarily in the areas of fertility and family planning and in the estimation of vital events for countries with inadequate vital registration systems. In 1973, along with P. Krishnan, he conducted the Growth of Alberta Families Survey, from which a number of important publications were produced as well as several graduate dissertations. One of Dr. Krotki's leading scholarly contributions is Population Growth Estimation: a Handbook of Vital Statistics Measurement, published in 1974 by the Population Council, with Eli S. Marks and William Seltzer. This book is considered essential reading for advanced students of formal demography. In 1993, Dr. Krotki, along with co-authors T.R. Balakrishnan and Evelyn Lapierre-Adamcyk, issued Family and Childbearing in Canada: A Demographic Analysis, (University of Toronto Press), the culmination of almost ten years of research based on the Canada Fertility Survey which Dr. Krtoki and his collaborators undertook in 1984. This survey remains the only national fertility survey in Canada.

Professor Krotki was not just an armchair scholar. Throughout his professional life he was involved in fieldwork and managing large scale operations and institutions. Hence he was very conscious of the importance of building up the necessary research tools and logistics, and he possessed the requisite "know-how." He also appreciated the importance of the outlet for scholarly output in the field of population studies. He was very much behind the launching of the Journal Canadian Studies in Population.

\section{Fellow of Royal Society of Canada, and other Positions}

In recognition of his outstanding scholarly achievements, Karol Krotki was elected as Fellow of the Royal Society, Canada's most prestigious academic body. As president of its Social Science section, he actively promoted the importance of demography in social science research and for public policy in Canada. For us demographers, the high point, "l'heure de gloire," was when two of our colleagues, Karol Krotki and Jacques Légaré, were elected, respectively, president and secretary of the Humanities and Social Sciences. In Légaré's own words,

in 1986, both of us were elected (the same year) on the Executive Committee of the Royal Society of Canada, he as President of the Academy of Humanities and Social Sciences and me as Honorary Secretary. The probability of seeing two demographers on this board at the same time was - and still is - very low. 
Throughout his long professional career, he was an active participant of many professional and academic conferences, committees, international agencies as consultant, as visiting professor and so on. Closer to home, mention should be made of his presidency of the Federation of Canadian Demographers (1981-1984). Among many other initiatives in support of demographic research, he was founder of the Society of Edmonton Demographers, an association whose aim is to promote demographic research in Alberta through an endowment fund.

\section{An Engaging Personality}

Professor Balakrishnan captured the essence of our friend and colleague:

He was bigger than life. He took great interest not only in his work but in his friends, family and in the world around him. He left an indelible mark on anyone he met. Living and working in Asia, Africa, Europe, United States and finally in Canada gave him a world view and experience which he shared with others. I was always awed by his depth of understanding of other cultures, especially of developing countries. Karol always spoke his mind and was not afraid to question conventional wisdom which sometimes got him into trouble. But then that was his strength.

Or as stated by another long-time friend of Karol, Anatole Romaniuc:

It is the totality of his personality that made his greatness - the combination of wisdom, entregent, friendliness, and scholarship through which he impacted various areas of our profession, in Canada and beyond.

Yet another testimony, this from his colleague and friend Susan McDaniel:

He had a lifelong deep respect for intellect, for ambition, and for engagement with the world of ideas. He didn't even mind when I disagreed with him rather forcefully, as young people who think they know more than they do tend to!

Finally, for his personality and his influence across cultural and linguistic boundaries, this excerpt from Sylvia Wargon's book, Demography in Canada in the Twentieth Century, is significant:

Krotki's European education, his international experience and contacts, and his French communication skills added a certain cachet to the population studies program at the University of Alberta, to which he continued to contribute on an emeritus basis after his retirement in 1990. (p. 180) 
Not least, as a true polyglot he could relate to people in their native languages.

\section{Grieving Family}

Karol left behind Joanna Elzbieta, whom he married when they both were students at Cambridge University. They were about to celebrate their diamond anniversary, 60 years of marriage. He left his close-knit family in sorrow: three sons, Karol Jr., Jan, and Filip, seven grandchildren and one great-grandson, as well as a sister in Poland.

\section{Anatole Romaniuk}

\section{T.R. Balakrishnan}

with the help of many of Krotki's friends and colleagues. 